\title{
A Contação e Cantação de Histórias: A Formação dos Sujeitos e a Manutenção das Práticas Culturais da Vila De Regência Augusta
}

The telling and singing of stories: the formation of subjects and the maintenance of cultural practices in the village of Regency Augusta

Patrícia Flávia dos Santos Cau Ailton Pereira Morila

Resumo: Regência Augusta faz parte do município de Linhares. Trata-se de um pequeno vilarejo rodeado pela foz do Rio Doce e o mar. Em maior parte, a comunidade é descendente da miscigenação entre indígenas, negros e brancos, comumente chamados na região de nativo ou caboclo. Estes sujeitos estão intimamente ligados a duas práticas culturais locais: a pescaria e o Congo. Nesse estudo, alguns apontamentos se mostraram expressivos: a memória coletiva e a transmissão dos saberes tradicionais, o trabalho da pescaria como prática cultural local e a proximidade entre a pesca e o congo. Os testemunhos aparecem nas ações de contação e cantação das histórias, influenciando e mobilizando a formação dos sujeitos. As identificações trazidas nas narrativas, tanto da Pesca como do Congo, demonstraram que as práticas contribuem para formação da vida prática, nos aspectos culturais e sociais da vila.

Palavras-chave: Memória Coletiva. Práticas Culturais. Saberes Tradicionais.

Abstract: Regência Augusta makes part of the city of Linhares. It is a small village surrounded by the mouth of the river Doce and the sea. Most of the community descends from the miscegenation of indians, black and white people, commonly named in the region as native or caboclo. Such actors are intimately bound to two local cultural practices: fishing and Congo. In this study, some notes were expressive: the collective memory and the transmission of traditional knowledge, the work of fishing as a local cultural practice and the proximity between fishing and Congo. The testimonies appear in the actions of telling and singing the stories, influencing and mobilizing the formation of the actors. The identifications brought in the narratives, both from Fishing and from Congo, demonstrated that the practices contribute to the formation of practical life, in the cultural and social aspects of the village.

Key-word: Collective Memory. Cultural Practices. Knowledge Tradition.

\section{Introdução}

Este trabalho apresenta um estudo sobre as práticas culturais da vila de Regência Augusta ${ }^{1}$, observando como as práticas culturais mobilizam saberes tradicionais da vila e influenciam na formação dos sujeitos locais. Por se tratar

\footnotetext{
${ }^{1}$ Regência Augusta faz parte do município de Linhares. Trata-se de um pequeno vilarejo rodeado pela foz do Rio Doce e o mar. Em maior parte, a comunidade é descendente da miscigenação entre indígenas, negros e brancos, comumente chamados na região de nativo ou caboclo. Estes sujeitos estão intimamente ligados a duas práticas culturais locais: a pescaria e o Congo.
} 
de uma comunidade tradicional, em que os saberes são compartilhados por meio da oralidade, na contação e cantação ${ }^{2}$ das histórias, a memória coletiva aparece como possibilidade de conservação e perpetuação desses saberes, sendo as histórias repetidas e ressignificadas nos acontecimentos sociais da vila. $O$ estudo foi realizado por meio de uma pesquisa de campo, usando como instrumento de coleta de dados a Metodologia em História Oral (Meihy, 2015).

A metodologia em História Oral necessita de uma aproximação direta com os sujeitos envolvidos na pesquisa. É um momento de conversa, com perguntas abertas, e embora haja um planejamento estruturado para o encontro, todo o momento é direcionado para que o entrevistado se sinta confortável e possa narrar sua história de forma espontânea no seu tempo e do seu jeito. Para Meihy (2015, p. 58) "Nada deve ser espontâneo num encontro de história oral. Apenas a liberdade de fala deve gozar de prerrogativas descontraídas. "

As entrevistas foram gravadas, transcritas e analisadas. Alguns fragmentos aparecem ao longo do texto. O estudo buscou interpretar os acontecimentos relacionando-os com o contexto em que foram criadas, considerando que os sujeitos constroem suas histórias no "processo de vivê-las" (GEERTZ, 1997).

A pesquisa se apoia em autores que discutem o conceito de história e memória com Halbwachs (2003) e Le Goff (2013). Por se tratar de uma comunidade tradicional não se poderia deixar de abordar a questão cultural, deste modo as reflexões de Burke (2008) e Canclini (1983) são os suportes teóricos. Nas análises dos dados se considerou, também, as concepções de Geertz (1997) sobre a interpretação das culturas. Em relação aos contadores/narradores da história, as teorias de Benjamin (1994) apoiaram as discussões.

\section{A memória coletiva e a práticas culturais locais}

\footnotetext{
2 Contação e cantação de histórias se refere ao hábito local de se contar histórias: tanto os pescadores na beira do rio ou do mar, como também nas músicas cantadas no congo. De forma geral, as histórias e as músicas se referem ao testemunho dos moradores da vila: falam sobre os santos, sobre a pesca, sobre os fatos heróicos e históricos significativos da comunidade.
} 
A vila de Regência Augusta fica na região litorânea do município de Linhares. Ao longo dos anos a comunidade tem se envolvido com práticas tradicionais locais como a pescaria, o artesanato, a devoção aos santos, as festas, as apresentações da banda de congo. Os primeiros moradores da localidade eram indígenas, e aos poucos com o desenvolvimento econômico da cidade de Linhares, brancos e negros também povoaram a vila. Esse encontro é observado na construção familiar dos moradores da vila de Regência Augusta. Dona Alda (2018) conta que "Aqui é tudo pé misturado, tem índio, branco, negro. A mãe do meu pai foi pega de laço. Minha mãe também era índia. " E da miscigenação desses povos os moradores da vila se autodenominam como caboclos ${ }^{3}$.

Ao iniciar este estudo, a pesquisa estava direcionada a investigar a prática cultural do congo da vila de Regência Augusta, tentando entender a manutenção do evento na dinâmica de interação entre os participantes da banda adulto e a banda de congo mirim. No decorrer das entrevistas, na análise dos testemunhos dos sujeitos envolvidos, e simultaneamente as leituras de Maurice Halbwachs (2003), que discute Memória Coletiva e no entendimento do que Burke (2008) chamou de história da memória, memória social ou memória cultural, observei que não conseguiria separar o trabalho da pescaria da prática cultural do congo. Os eventos são mobilizados pelos saberes tradicionais da memória desses sujeitos, numa dinâmica de interação e construção individual e coletiva. Dessa forma, o trabalho da pescaria neste estudo é tratado como uma prática cultural tradicional da vila.

Tomemos como exemplo, o testemunho de Dona Alda ${ }^{4}$, pescadora e conguista local, a história dela está relacionada ao contexto social da vila. Ela diz "A minha história é (pausa) até uns anos atrás eu pescava". Quem é ela está

\footnotetext{
${ }^{3}$ Caboclo segundo o dicionário da Língua Portuguesa Houaiss: 1 mestiço descendente de índio e branco 2 caipira, roceiro matuto. Adj. 3 relativos a esse mulato e caipira, seus aspectos, seus hábitos, sua índole 4 da cor morena do cobre. O conceito de Caboclo usado no propósito desse trabalho vai além da ideia de descendente de índio e branco, mas também da concepção dos moradores da vila que se autodenominam caboclos por serem nativos da região.

${ }^{4}$ Dona Alda Ribeiro Lourenço Ivo. Nascida em Regência Augusta,70 Anos, pesca e faz trabalhos manuais com linhas.
} 
condicionada as histórias construídas na vivência com a prática da pescaria local. Ela não consegue separar sua identidade das relações sociais. E quando ela não consegue se identificar diante do contexto atual, ela se remete ao passado. "Até uns anos atrás eu pescava." Ela se apega a prática cultural da pesca para falar de sua história. As lembranças são essas experiências trazidas do passado que se materializaram por meio das histórias contadas. E por sermos seres sociais não podemos separar a história individual da história coletiva.

Em outra história, Leônidas Carlos $^{5}$, também pescador e conguista, diz que a história dele começa a ser contada a partir de recordações do tempo de criança, ele descreve que passava horas à beira do rio vendo o trabalho com peixe, observava atentamente a entrada e a saída dos barcos, a puxada da rede e a retirada do pescado. "Minha infância, meu pai me levava muito para roça, não tinha muito estudo não, eu pedia ao meu pai para pescar de lança e meu pai não deixava. Ele era jangadeiro, não era pescador. E eu ia escondido. Deixava de ir para a escola. " (LEÔNIDAS CARLOS, 2018)

$\mathrm{Na}$ entrevista de Zé de Sabino ${ }^{6}$, pescador e filho do primeiro mestre da Banda de Congo de Regência Augusta, ele conta que "A minha história começa pelo nome lá em casa. O nome do meu pai é Sabino Bispo, aí por morar no interior e todo mundo ser um pouco Zé de alguma coisa: Zé de Oliveira, Zé de Juju e eu era o Zé de Sabino, mas meu nome é Élcio José Souza de Oliveira”. A história de Zé de Sabino está diretamente relacionada a história do pai e a de outros pescadores que também são Zé de alguém, a formação foi elaborada dentro de uma construção social, ele é Zé filho de alguém, ele é Zé pescador. A história do pai, a história de Zé de Sabino e a de tantos outros pescadores estão entrelaçadas pela significação que a prática cultural possui na vida do grupo. Para Halbwachs (2003, p.68), "[...] se a memória coletiva tira sua força e sua

\footnotetext{
${ }^{5}$ Leônidas Carlos é presidente da Associação de Pescadores de Regência Augusta (ASPER). A associação recebeu o nome de Sabino Bispo de Oliveira em homenagem a dedicação e compromisso que Sabino sempre prestou aos pescadores como também seu envolvimento com Congo e com toda comunidade da vila.

${ }^{6}$ Elcio José Souza de Oliveira, Zé de Sabino, atualmente com 51 anos de idade é um participante ativo da vila, assim como seu pai, ele faz parte da associação de pescadores no cargo de tesoureiro, ajuda na associação de moradores atuando no conselho fiscal, e depois do crime ambiental (será tratado mais a frente) é membro do conselho consultivo da Fundação Renova.
} 
duração por ter como base um conjunto de pessoas, são os indivíduos que se lembram, enquanto integrantes do grupo".

É importante ressaltar a relação íntima da comunidade com o rio e o mar. A boca da barra é um lugar de encontro, um lugar de construção social de vivências e de formação dos sujeitos nas práticas tradicionais. As crianças, de olhos e ouvidos atentos, observam com curiosidade as práticas: querem aprender com o pescador o manejo do barco, o ritual para puxada da rede, escutam as conversas sobre os ventos e mudança de mares, os casos de peixes grandes, as aventuras que acontecem mar adentro, e assim dia após dia constroem suas experiências em relação ao rio, ao peixe. "[...] a partir daí compreenderemos melhor que a representação das coisas evocada pela memória individual não é mais do que uma forma de tomarmos consciência da representação coletiva relacionada às mesmas coisas. " (HALBWACHS, 2003, p.61).

Esse é o mesmo lugar onde Leônidas Carlos aprendeu a pesca, aprendeu sobre o vento, a entrada e saída de barcos, ouviu histórias dos antigos pescadores; é também o lugar onde Luciana Oliveira ${ }^{7}$, responsável pela banda de congo mirim, descreve momentos felizes da sua infância, é o lugar também onde Abdon Claudino ${ }^{8}$, poeta e músico local, criou grande parte das suas poesias e músicas, é o lugar onde histórias são construídas, compartilhadas e ressignificadas.

\section{História da banda de congo São Benedito de Regência Augusta}

\footnotetext{
${ }^{7}$ A entrevista com Luciana Oliveira foi realizada em janeiro de 2018. Luciana Souza de Oliveira é professora de Língua Portuguesa e trabalhou nos anos anteriores na escola E.E.F.M Vila Regência. Atualmente ela é responsável pelo ensaio da banda de Congo-mirim. É nativa da vila, filha do pescador Sabino Bispo (um dos primeiros mestres do Congo São Benedito). Ela se envolve em vários projetos da vila. Recentemente criou a marca "Pimenta Nativa". Junto com costureiras locais e com a ajuda do projeto TAMAR produz uma linha de camisas dialogando com as práticas culturais de Regência. Trabalha no posto de saúde da vila e participa da Associação de moradores.

${ }^{8}$ Abdon Claudino é um poeta local, compositor de grande parte do repertório de músicas da banda de Congo de Regência (São Benedito). Faleceu em fevereiro deste ano (2018), período em que eu estava na vila por causa dessa pesquisa. Sua morte foi uma grande perda para a comunidade local. Escreveu um livro de poesia chamado Regência em Prosa e Verso no ano de 2011, onde mostra com muita sensibilidade a beleza da vida e do cotidiano da vila.
} 
As bandas de Congo têm origem indígena. É o que diz Lins (2009) no livro "O Congo do Espírito Santo: Uma panorâmica musicológica das bandas de Congo", trazendo relatos de Guilherme Santos Neves, Padre Antunes de Sequeira e Auguste-François Biard em que informações descritas em diários náuticos comprovam que práticas semelhantes foram vistas no início do século XIX na região capixaba. Os primeiros viajantes que passaram por essas terras fizeram descrições gerais dessas atividades, sem muito interesse nos detalhes, pouco se sabe o que era cantado, o motivo dos arranjos e a disposição dos elementos nas performances. Lins $(2009$, p. 25) explica que,

Infelizmente, os primeiros documentaristas de nossas bandas de Congo não registraram o que era cantado pelos conjuntos de então. Padre Antunes da Sequeira, citados por Guilherme Santos Neves afirma que, "acocoram-se todos em círculo, batendo com as palmas das mãos no peito e coxas, e soltando guinchos horríveis. Fazem caretas e trejeitos, acompanhados de uma música infernal. Auguste-François Biard opina que os índios de Santa Cruz "não cantavam, gritavam" (...)

Considerando o período dos relatos trazidos por Lins (2009), as bandas de Congo teriam surgido por volta de 1855 , data próxima a abertura da navegação do Rio Doce, e dos primeiros relatos de reconhecimento das terras ao redor da área de passagem pelo rio. Nesse processo, Lins (2009, p.29) descreve que,

Originadas de índios e mescladas posteriormente de elementos europeus e africanos, as outrora "bandas de índios ", depois "bandas de tambor", passaram a ser denominadas "bandas de Congos", expressão que, na atualidade, foi simplificado para "bandas de Congo"

Como destaca Lins (2009) na citação acima, a prática passou por processos de mudança, absorvendo influências dos negros escravos e dos colonizadores europeus.

Aos negros se atribui a inserção de um ciclo rítmico chamado de "padrão luba". Esta estrutura rítmica também é encontrada no frevo e no maracatu. (LINS, 2009, p.30). Por outro lado, a referência europeia está na melodia quase sempre tonal:

Fruto da herança musical portuguesa no Brasil, o tonalismo (sistema harmônico ocidental) só não se fixou entre nós na música religiosa de origem africana, como é o caso do candomblé e de outras religiões afro 
brasileiras [...]constante no nosso folclore desde "Ciranda cirandinha", - sistema tonal é fundamento básico de toda a música popular brasileira. (LINS, 2009, p.67)

Em relação ao nome "Banda de Congo", Lins (2009, p.30), explica ainda,

As expressões Congo, congado, conguês, terno de Congo, Congo de máscaras, Congo de calçola, rocongo, sinfônico, e outras que, no âmbito da música recorrem às palavras Congos ou Congo, remetem, todas elas, ao antigo Reino do Congo, o maior Império que se tem notícia na África, até 1942, quando Diogo Cão, navegador português, "descobriu" a bacia do rio Zaire.

Em 1902 a partir do Tambor de Congo ou Tambor de São Benedito a prática já é descrita com recorrência na região do Espírito Santo. Contudo, "[...] apenas em 1951, por ocasião dos festejos comemorativos do IV Centenário da fundação de Vitória, que o ritmo do Congo entrou oficialmente nos festejos culturais no Espírito Santo, acontecendo nesta data a primeira concentração de Bandas de Congo." (BERGAMIM, 2017). Em específico em Regência Augusta se tem registro do congo nos festejos comunitários desde 1930 (Informação retirada do Museu Histórico de Regência).

Moradores mais antigos da vila contam que, antigamente, a banda de Congo São Benedito de Regência Augusta era chamada de dois Tambores e dois Ganzás e apenas estes instrumentos eram usados. Os tambores eram confeccionados de troncos de árvores ocas e revestidos com couro e os ganzás, pedaço de madeira com cabeça esculpida, barriga oca, revestida com taquara que só existe no Espírito Santo, conhecido também como casaca ou reco-reco. Leônidas Carlos (2018) "Antes eram dois tambores e dois ganzás, depois outros instrumentos foram sendo colocados".

Os conguistas se revezavam comandados pelo capitão que conduzia o ritmo usando um apito e um bastão na mão. (LINS, 2009). Dona Alda (2018) conta que "De primeiro eu tocava ganzá, que muitos chamam de reco-reco, mas na nossa língua chamamos de ganzá ${ }^{9}$. É a nossa língua, a língua do índio né?

Sobre a origem do nome da banda de Congo São Benedito acredita-se que seja pela devoção ao santo. Lins (2009, p. 25) comenta que,

\footnotetext{
${ }^{9} \mathrm{~A}$ palavra é de origem africana. "Ganzá" se originou do quimbundo nganza, que significa "cabaça".
} 
No Espírito Santo, as bandas de Congo são profundamente ligadas à religião e principalmente à festa de São Benedito e abrimos aqui um parênteses para explicar um pouco essa ligação. No estado do Espírito Santo, mais especificamente no município da Serra, a festa ocorre entre os dias 24 e 27 de dezembro, mas pode ter suas datas alteradas em outros municípios. Segundo Elmo Elton em seu livro São Benedito,sua devoção no Espírito Santo, a devoção este santo, no estado, vem desde o século XVII e é posterior a 1686. Embora a igreja católica celebre oficialmente o dia de São Benedito na data de sua morte 4 de abril de acordo com catálogo oficial da Igreja Católica Romana era costume naquela época os senhores da região virem a sede da cidade para celebrar o natal e traziam consigo seus escravos e Bugres. Estes aproveitando a ocasião celebravam também a festa de São Benedito no dia 25 de dezembro. Tal costume permaneceu até 1833 quando o padre André Massela transfere a festa para o dia 26 de dezembro. A devoção a São Benedito e sua ligação com as bandas de Congo vem a partir de uma lenda que conta a história do Navio Negreiro Palermo que traria uma leva de escravos para o Brasil e naufragou no litoral de Nova Almeida,Espírito Santo, conta-se que os negros se salvaram agarrados ao mastro do navio orando a São Benedito, origina-se aí é fincada do mastro de São Benedito nas praças das igrejas.

Em 1976 quando a banda de Congo Vila do Riacho, que já usava vários tambores e casacas veio a Regência, a Banda de Congo São Benedito de Regência passou a utilizar também, mais tambores, ganzás, triângulos e chocalho, consequentemente incluindo um maior número de integrantes segundo Leônidas Carlos (2018).

Daí adiante as atividades foram organizadas pelos capitães ${ }^{10}$ (mestres) que estão à frente da prática e orientam as apresentações, ensaios, viagens, guiam o ritmo e criam a maioria das músicas.

\section{Memória coletiva e a manutenção das práticas culturais locais}

A criação da Banda de Congo Mirim surge do desejo de sustentação dos saberes tradicionais. As crianças tendo contato com os mais velhos, conhecendo sobre o trabalho e os sentidos do Congo e ao mesmo tempo sobre as histórias de santos, de heróis, da pesca, num processo de construção histórico e cultural das práticas. Por outro lado, os mais velhos teriam um público disposto a ouvir e

10 O mestre também é chamado de capitão no Congo de Regência Augusta. 
aprender com as histórias, valorizando as experiências, o fazer manual, as crenças e as origens. Benjamin (1994, p.221) questiona,

[...] se a relação entre o narrador e sua matéria prima - a vida humana - não seria ela própria uma relação artesanal. Não seria sua tarefa trabalhar a matéria-prima da experiência - a sua e a dos outros transformando-a num produto sólido, útil e único?

Tentando responder a inquietação trazida por Benjamin (1994), no contexto da Vila de Regência Augusta, poderíamos dizer que a memória coletiva seria um produto construído por esse armazenamento de experiências estabelecido ao longo dos anos. É comum aos moradores mais velhos da vila a prática de contação e cantação de histórias, transmitindo por meio da tradição oral, um conjunto de conceitos, valores e representações historicamente elaboradas pela comunidade.

Cabe observar, que muitas vezes, essa ação acontece sem a elaboração de uma estrutura complexa, é muito mais espontânea e instintiva, contudo o que vemos e não poderíamos ignorar, é a ação pedagógica desses encontros. São momentos atravessados por uma significação própria e reflexiva da comunidade.

Sangália (2018) ${ }^{11}$ conta que o Congo Mirim foi criado em 1987 por vontade de Dona Mariquinha junto a outras lideranças comunitárias: Ilona Húngara, Alaíde, Elenita, Eliar. A Banda de Congo Mirim Caboclo Bernardo foi a primeira Banda de Congo de Crianças do Estado do Espírito Santo.

Foi aí que Bibiu conseguiu lá no DEC (Departamento Estadual de Cultura) todos os panos, tecidos para fazer roupa do Congo Mirim. As mulheres daqui costuraram, depois ela conseguiu todos os instrumentos do Congo Mirim, que eram as barrigas igual era do Congo lá de Vitória, que foi o mestre Antônio Rosa, lá da Serra que fez. O mestre Antônio Rosa é referência do Congo Capixaba. E dessa época uma parte das pessoas que já faleceu.

11 Carlos Sangália nasceu em Linhares. Formado em Arte Educação. Trabalha no Projeto TAMAR com Educação Ambiental e Desenvolvimento Comunitário (fomentação de instituições comunitárias, projetos culturais, educação ambiental com a escola, artesanato). Para além do trabalho no Projeto TAMAR se envolve com questões sociais e culturais da vila desde 1987. Junto com a comunidade Carlos Sangália ajudou a fomentar algumas associações em Regência Augusta: Em 1998 foi criada a Associação de Moradores em ocasião do SOS Regência; em 1888 foi criada a Associação de Pescadores; Ajudou a criar a Associação de Artesanato; A Associação do Congo São Benedito de Regência Augusta. 
Com o passar dos anos as crianças da Banda de Congo Mirim Caboclo Bernardo foram crescendo e a Banda acabou. Em 2012 surge um projeto Mais Cultura na Escola e a Banda de Congo Mirim começa a surgir numa nova proposta se unindo a escola. Glória (diretora) e a professora Luciana começaram a desenvolver um trabalho de identidade cultural de Regência, num esforço de resgate da prática por meio de oficinas, que exploravam os significados do Congo para comunidade.

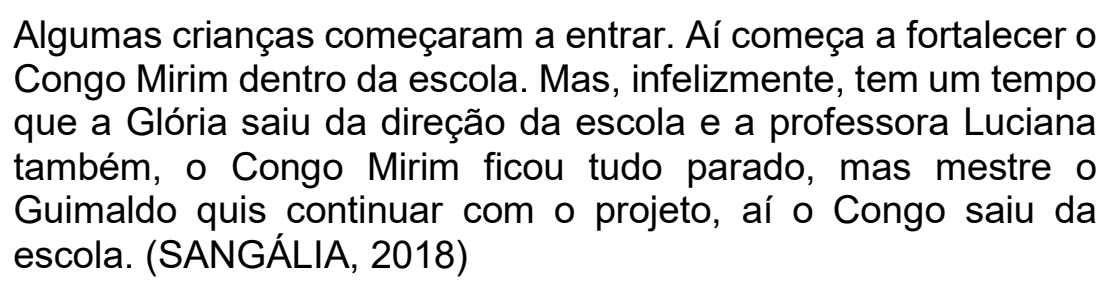

No espaço escolar, a elaboração intelectual das significações comuns a comunidade se apresenta articulada aos conteúdos obrigatórios do currículo. A tentativa do projeto foi sistematizar o conhecimento popular das práticas culturais locais e, ao mesmo tempo, agregar valores culturais ao currículo. Mas o projeto não funcionou por muito tempo.

No projeto elaborado justificando a inserção do Congo na escola encontramos o seguinte objetivo,

O projeto tem como objetivo auxiliar a comunidade escolar a sensibilizar a população local em relação à preservação das tradições culturais locais, principalmente o Congo. Apesar de essa manifestação fazer parte do calendário cultural do distrito de Regência Augusta é pouca difundida e preservada, fato em que a E. E. E. F.M Vila Regência passou a tratar tal manifestação como pesquisa dos múltiplos saberes populares a ser sistematizado e transformado em conhecimento acadêmico no conteúdo escolar. (PROJETO CONGO MIRIM.)

O trabalho desenvolvido na escola, por meio do projeto, retoma e valoriza as memórias coletivas da vila sobre os aspectos culturais das práticas. As crianças se aproximam das narrativas históricas e da coletividade existente e próprias da comunidade. Estes desdobramentos revelam saberes e reforçam a identidade cultural tanto da prática da pescaria quanto do congo. Durante o ano, algumas oficinas são oferecidas aos tocadores mais novos. De um desses momentos Oliveira (2018) conta que, 
Mestre Umberto ensinou os meninos a fazer a casaca e enquanto isso eles iam ouvindo as histórias dos antigos mestres e ajudou a enriquecer a identidade cultural das crianças e é muito diferente construir seu próprio instrumento, tem sua identidade. As crianças foram para a mata para ver qual o tipo de madeira utilizar para a casaca e também aprenderam a fazer redes de pesca.

O trecho acima narrado por Oliveira (2018) fala especificamente de uma experiência de oficina com a Banda de Congo Mirim. A vivência permitiu aos aprendizes refazerem o caminho dos primeiros conguistas, desde a escolha e retirada de material da natureza à produção coletiva de objetos manuais. Ao mesmo tempo, eles conhecem as histórias do passado que são contadas e cantadas durante a feitura das peças por meio da transmissão oral das histórias e das músicas. E aqui se retoma uma história trazida por Mestre Guimaldo em uma de suas primeiras lembranças construída em torno do Congo, revivendo o mesmo processo de feitura de instrumentos musicais que as crianças. "Tudo aqui era mata virgem, a gente entrou nessa mata doida pra catar aquelas toras broqueadas. Cortamos em tamanhos de 40 e $50 \mathrm{~cm}$. e fizemos 10 pedaços. Deu pra fazer 10 tambor, 10 ganzá e 1 cuíca. E saímos para brincar."

Ao retomar a história do passado e compartilhar no tempo presente Mestre Guimaldo cria um elo, permitindo que as crianças construam ou simulem a lembrança trazida por ele, se apropriem dela de acordo com suas percepções. Para Benjamin (1994, p.210) "[...]a relação ingênua entre o ouvinte e o narrador é dominada pelo interesse em conservar o que foi narrado".

A prática de contação de histórias é bastante comum na vila, os mais velhos sentem prazer e orgulho de suas histórias, querem manter viva as lembranças, as práticas encentrais, seus hábitos e costumes. Benjamin (1994, p. 205) diz que "Contar histórias sempre foi a arte de contá-las de novo, e ela se perde quando as histórias não são mais conservadas. Ela se perde porque ninguém mais fia ou tece enquanto ouve história."

Hoje, o Congo Mirim de Vila Regência são os alunos da escola, mas não estão diretamente ligados à escola, eles estão dentro da Casa de Congo junto com Mestre Guimaldo e as professoras Luciana e Morena. Junto com a comunidade. 
Para a Banda de Congo Adulto ter as crianças perto representa simbolicamente a renovação e consequentemente perpetuação da prática. As crianças mantêm viva a esperança de dias melhores, o desejo de continuar existindo e resistindo às problemáticas econômicas, sociais e culturais. As crianças hoje representam o motivo de continuar cantando e compartilhando a memória.

Ao falarmos de memória coletiva dentro de comunidades tradicionais acreditamos que as festas são momentos de reviver as histórias e fortalecer as práticas culturais locais, mantendo por meio da transmissão oral de contação e cantação os saberes tradicionais da comunidade.

\section{Contação e cantação das histórias: a formação do sujeito para vida prática}

As festas são sempre momentos de resistência e força, de ressignificação e atualização das práticas, uma maneira de continuar existindo, adaptando-se às necessidades do tempo. De forma espontânea e natural essa transmissão de saberes tradicionais constrói vínculos sociais afetivos de pertencimento, construindo entre os membros dos grupos ou comunidades elementos comuns a todos. Halbwachs (2003, p.165) diz que, "Os grupos [...]estão naturalmente ligados a um lugar, porque é o fato de estarem próximos no espaço que cria entre seus membros as relações sociais[...]"

O ciclo festivo do congo em Regência Augusta envolve três momentos específicos: começa com Fincada do Mastro em novembro (em devoção a Santa Catarina), Derrubada do Mastro em Janeiro, (festa de São Sebastião) e a festa de Caboclo Bernardo em junho, uma homenagem ao Herói Caboclo Bernardo. É importante dizer que existem outras festas na vila durante o ano, mas as citadas foram as celebrações descritas durante as entrevistas como festividades tradicionais em que as Bandas de Congo se apresentam e por isso a importância para o trabalho. Gilberto Giménez (apud CANCLINI,1983, p.113) aponta algumas características das festas tradicionais,

a)Ruptura do tempo normal; b) Caráter coletivo do fenômeno da festa, sem exclusão de nenhuma classe, como expressão de uma comunidade local; c) Caráter compreensivo e global, uma vez que a festa abrange os elementos mais heterogêneos e diversos sem 
disgregação nem "especialização" (jogos, danças, ritos, música etc. ocorrem no interior de uma mesma celebração global; d) Com a consequente necessidade de ser realizada em grandes espaços abertos e ao ar livre (praça, o pátio da igreja...) e) Caráter fortemente institucionalizado, ritualizado e sagrado(a festa tradicional é indissociável da religião); f) Impregnação da festa pela lógica do valor de uso(como consequência: festa-participação e não festaespetáculo); g) Forte dependência do calendário agrícola no quadro de agricultura sazonal.

Das particularidades citadas acima observamos que a maioria delas condiz com as três festas descritas como tradicionais de Regência Augusta. São ditas festas tradicionais os eventos festivos que assumem as expressões culturais da comunidade e se realizam dentro de um sentido de reprodução simbólica de práticas e vivências compartilhadas comuns aos moradores. Como já falamos, essas festas são abertas, com interação constante com o público. Normalmente fazem caminhadas pela vila, indo em cortejo da igreja a casa do Congo ou vice-versa.

Se distingue do "calendário agrícola", e segue um calendário ligado às questões religiosas, aos santos e heróis, fortemente unida aos elementos do rio e o mar e a pescaria. Não se nota também o aspecto de "ruptura com o tempo normal", mas metaforicamente podemos dizer que o tempo, durante as festas, adota um momento de suspensão, onde passado, presente e futuro convergem reciprocamente se influenciando.

Vemos nesta ocasião a função da memória coletiva em assumir um desempenho essencial que se movimenta entre as representações de práticas tradicionais às experiências do tempo presente, atualizando as histórias do passado. Para Le Goff (2013, p. 437), “A memória na qual cresce a história, que por sua vez alimenta, procura salvar passado para servir ao presente e ao futuro."

Ao examinarmos as três festas citadas acima verificamos que elas representam o interesse de perpetuação das práticas culturais da vila. Para a maioria dos moradores conservar as manifestações locais é uma questão muito maior do que o desejo de promoção econômica. São momentos em que o fazer cotidiano, as práticas culturais e a memória coletiva estabelecem meios de sobrevivência na ação repetitiva e alegórica da festa. A análise de Canclini (1983) sobre a interferência mercadológica em comunidades tradicionais 
distingue as celebrações que ocorrem no interior dessas comunidades como elemento de força e resistência diante dos conflitos entre os sistemas culturais.

As festas em Regência Augusta são momentos especiais na vida cotidiana da vila. Grande parte da comunidade elabora e reestrutura seu dia a dia considerando o calendário festivo. É um preparo que começa muito anteriormente ao evento e como são três encontros anuais, divididas entre os meses do ano, início, meio e fim - a comunidade se ocupa entre os afazeres do dia-a-dia, aos ensaios, arrumações, decorações, produções de artesanatos para venda e apreciação, hospedagem, alimentação e recepção dos turistas. Lembrando Canclini (1983) essa organização coletiva é uma das características das festas populares tradicionais. Ele diz ainda que,

\section{As festas camponesas, de raízes indígenas, coloniais, e ainda as festas religiosas de origem recente são movimentos de unificação comunitária para celebrar acontecimentos ou crenças surgidas da sua experiência cotidiana com a natureza e com outros homens [...].(CANCLINI 1983, P.54)}

De modo geral, no Espírito Santo, a festa relacionada ao Mastro se divide em três momentos, "1. Derrubada ou arrancada do mastro; 2. Puxada, levantamento e fincada do mastro; 3. Retirada ou descida do mastro. A derrubada - em que é abatida uma árvore na mata para servir de mastro na festa. " Atlas de Folclore Capixaba (2009, p.88)

A primeira festa do ano é a festa em homenagem a Santa Catarina, acontece a tradicional "Fincada do Mastro" ou "levantada do mastro". O evento é realizado no final de semana próximo ao dia 25 de novembro, quando é feita a procura e levantada do mastro. A Banda de Congo São Benedito, de Regência Augusta, é a única banda de congo do Espírito Santo que faz a Fincada nesta época do ano.

Os conguistas saem à procura do mastro que foi escondido na noite anterior. Após acharem, o Mastro é levado, em meio a brincadeira e cantoria, até a igreja onde é fixada a bandeira de Santa Catarina e São Benedito. Para Dona Alda (2018), "É um momento de fé". E continua,

Na festa de Santa Catarina a gente faz a comida, nós somos em três cozinheiras. No ano passado, em novembro, eu fiz uma promessa para Santa Catarina. Eu estou muito doente com uma 
tosse forte, fiz uma promessa que se Santa Catarina me deixasse eu boa pra 'mim' pode cantar de novo a cantiga do Congo, eu ia de casa até a igreja de joelhos. Minha filha, eu estraguei meu joelho, mas a promessa foi cumprida. Fui nascida e criada na igreja católica. Deus e São Benedito vai ser meu curador! E eu vou ficar boa.

O Atlas de Folclore Capixaba descreve que,

No dia ou na véspera do dia do santo, dá-se a puxada do mastro, já preparado e ornamentado para conservar no topo, depois de fincado, um quadro em forma de tela com a figura do santo. [...] Tanto a puxada como a fincada do mastro são marcadas por intenso foguetório e pelo som das batidas e toadas das bandas de congo. Antes de ser fincado no local onde permanecerá por algum tempo, o mastro é atirado várias vezes para o ar e recebido nos braços dos devotos que dançam e cantam com entusiasmo. A retirada, retirada ou descida do mastro somente ocorre meses depois, quando se dá por encerrado o ciclo de homenagens ao santo, e mais uma vez as bandas de congo participam do evento. Atlas de Folclore Capixaba ${ }^{12}$ (Atlas de Folclore Capixaba, 2009, p.71)

Para completar o ritual, o Mastro é fincado em frente à igreja, permanecendo ali até o mês de janeiro. As festas relacionadas ao Mastro são ocasiões mais intimistas, com pouca participação de turistas e consequentemente pouco investimento financeiro. Por um lado, vemos uma prática que sofre menos interferência externa por ser mais restrita.

A Festa da Derrubada do Mastro que acontece em janeiro, próximo a data de São Sebastião. Um ponto fundamental dessa festa é a procissão que segue pelas ruas da vila entoando as músicas do Congo e as rezas tradicionais da igreja católica, Salve Rainha, Ave-Maria, Pai Nosso, Santa Maria, Santa Catarina.

As comemorações que envolvem a Fincada e a Derrubada do Mastro fazem alusão a uma história antiga sobre o naufrágio de um navio negreiro, em que os tripulantes, a maioria negros escravizados, conseguem se salvar segurando ao Mastro do navio. De acordo com o Atlas de Folclore Capixaba (2009, p.88),

\footnotetext{
${ }^{12}$ Atlas do Folclore Capixaba / Usina de Imagem; Coordenação de Humberto Capai ; Fotografias da Usina de Imagem - Espírito Santo, SEBRAE, 2009.
} 
A tradição tem propagado a versão de que escravos se salvaram de um naufrágio sustentando - se ao mastro do navio. Devido a essa crença, as Bandas de Congo seguem o ritual do mastro, fazendo as festas da Arrancada, Cortada ou Derrubada; da Puxada e Fincada; e da Retirada do Mastro de São Benedito.

A história dos escravos que se salvaram de um naufrágio agarrados ao mastro vem sendo contada há anos. A ideia de bravura e heroísmo se perpetua em cada novo ciclo. E esse sentimento de manter vivo as histórias é tão forte para as comunidades tradicionais, que se torna necessário criar momentos envolvendo os acontecimentos significativos à memória social do grupo, numa tentativa de que o fato possa continuamente ser lembrado. Canclini (1983, p.126) diz que a festa é um momento de tensão entre "o passado e o futuro, o perdido e o prometido". O encontro dos tempos, na relação que se constrói entre os participantes mais jovens e os mais velhos. " No momento de rememoração das histórias, os ouvintes que se identificam com as situações descritas sofrem um processo de reconhecimento, de afinidade, tomando para si a história. Benjamin (1994, p.211) acredita que "A reminiscência funda a cadeia da tradição, que transmite os acontecimentos de geração em geração. "

A memória sobre o evento passa a pertencer a este ouvinte, de maneira que mesmo não vivendo essa experiência, cria a sensação de pertencimento. Halbwachs (2003, p. 108) explica que, "No momento em que examina seu passado, o grupo nota que continua o mesmo e toma consciência de sua identidade através do tempo. "Assim, as pessoas, também, constroem suas histórias com base na memória dos outros, as histórias contadas por outros, as experiências dos avôs, dos parentes, vizinhos e vivem essas memórias como se fossem suas, mesmo que muitas vezes não as presenciaram, por terem ocorrido há muito tempo. E nessa organização se verifica a possibilidade de permanência e preservação da memória coletiva.

Segundo o pensamento de Halbwachs (2003, p.109) A memória coletiva "[...] apresenta ao grupo um quadro de si mesma que certamente se desenrola no tempo, já que se trata de seu passado, mas de tal maneira que ele sempre se reconheça nessas imagens sucessivas. A memória coletiva é um painel de semelhanças [...]. "A festa reconstrói o cenário, na repetição simbólica, revivendo o momento do naufrágio. É também o momento de conflito entre as 
transformações sociais e o desejo de permanência e continuidade das tradições. "Os atos cerimoniais não devem ser separados dos cotidianos. " (CANCLINI, 1983, P. 128)

Le Goff (2013) comenta que a palavra memória na antiguidade clássica foi atribuída a deusa "Mnemosine" responsável por recordar aos homens os feitos dos heróis. E aqui, vemos uma história heróica, de sobrevivência, de força, de luta, de um povo que por anos vem sendo subjugado, todavia se reafirma na coletividade e nas histórias do seu povo. Benjamin (1994, p. 210) completa dizendo que "A memória é a mais épica de todas as faculdades."

Com isso, podemos dizer que a memória social permite ao indivíduo ou um grupo, experimentar o que não viveu, durante as festas os participantes experimentam a rememoração da cultura, dos saberes e das práticas, retomam e fortalecem as origens culturais.

Diferentemente das festas que envolvem o Mastro e os santos, a festa de Caboclo Bernardo é genuinamente de Regência Augusta, o festejo ao herói acontece próximo a data de sua morte, 03 de junho. A data do evento guarda a lembrança da morte do herói. Le Goff (2013, p.408\409) explica que "A associação entre a morte e a memória adquire, com efeito, rapidamente, uma enorme difusão no cristianismo, que a desenvolveu na base do culto pagão dos antepassados e dos mortos. " Uma forma de homenagear após a morte pessoas geralmente benévolas, conservando na memória da comunidade a data de sua morte.

Este evento não se realiza em nenhum outro lugar. São três dias de comemoração, e o ponto alto acontece no domingo com o encontro das Bandas de Congo que vem de vários municípios do Espírito Santo. As comemorações do feito heróico de Caboclo Bernardo acontecem desde 1930 (REIS, 2003) com o Auto do Caboclo Bernardo ${ }^{13}$. A festa com a proposta de "Encontros de Bandas de Congo" só começou em 1991. Essa lembrança é narrada por Sangália (2018),

A gente estava lá em Vitória ajudando o Congo de lá, ai dona Mariquinha e Claudio Lins apareceram por lá, com a seguinte ideia: "estamos querendo levar mais Congo lá na festa Caboclo

\footnotetext{
${ }^{13}$ Alto do Caboclo Bernardo é uma peça teatral que retrata o nascimento, a infância na beira do rio, o salvamento, a condecoração e a morte de Caboclo Bernardo.
} 
Bernardo porque a festa é só futebol e tal." E como a gente tinha muito contato lá em Vitória, a gente conseguiu o apoio da UFES, convidamos várias Bandas do Estado, a gente tinha muito contato. Por causa do apoio da UFES, precisamos colocar no cartaz do evento como o segundo encontro da Banda de Congo, mas era o primeiro, tinha que ser evento que já havia começado, aí a gente falou "esse aqui já começou já" (rindo). Aí organizamos o encontro de Bandas de Congo em Regência Augusta na festa do Caboclo Bernardo. Recebemos 10 Bandas neste ano, em 1992 nos mudamos pra cá e continuamos a ajudar na organização da festa.

É a festa mais popular da vila. Normalmente um grande número de turistas enche o lugar. Nesta festa também há apresentações de shows musicais regionais e nacionais, atividades esportivas, barracas de produtos e comidas típicas, mais parecida com o que Canclini (1983) chama de festa espetáculo.

Quando questionada sobre como é a festa, Dona Alda (2018) descreve a celebração explicando o lado ritualístico, o encontro das Bandas de Congo, a entrada na igreja, o respeito aos santos. Em nenhum momento ela fala sobre as outras atividades que acontecem durante o final de semana, shows nacionais, teatro, apresentação de danças etc. Para ela, a festa era naquele momento do Congo.

\begin{abstract}
Na festa do Caboclo Bernardo a gente faz uma caminhada lá do começo da vila até a igreja. Vem um monte de bandas do Congo de fora. A chegada na igreja é a parte de muita alegria, parece que a gente está entrando no céu assim. Quando a gente chega dentro da igreja com aquele pessoal todo do Congo é muito emocionante. A gente entra e faz uma continência no altar, dança e canta e a gente sai e deixa os outros entrarem pra fazer a continência deles. Depois da igreja a banda vai para pracinha da vila e ali encerra a festa. Ai a gente vai na casa de Congo para guardar os instrumentos. Dona Alda (2018)
\end{abstract}

De forma semelhante o Atlas do Folclore Capixaba (2009, p.82) descreve a festa do Caboclo Bernardo como um evento basicamente tradicional, de comemoração ao ato heroico e aos festejos da Banda de Congo,

Festa realizada há mais de 60 anos em Regência, distrito de Linhares, em homenagem ao Caboclo Bernardo, filho mais ilustre de Regência, condecorado pela Princesa Isabel em 1887, como herói nacional, por salvar de naufrágio, na foz do rio Doce, 128 marinheiros do navio Imperial Marinheiro. Bernardo José dos Santos, o Caboclo Bernardo, recebeu na corte do Rio de Janeiro uma medalha humanitária de primeira classe cunhada em puro ouro. Os grupos folclóricos da região, Bandas de Congo, Reis de Boi e Ticumbi, festejam esse herói, consagrado 
como santo pela comunidade local. No dia seguinte se realiza o Encontro de Bandas de Congo, com a participação de bandas da região. O público estimado para esse evento é de 5.000 pessoas. Data: primeiro final de semana de junho, data móvel.

A organização dessa festa é compartilhada com a Associação de Moradores de Regência Augusta, por demandar mais recursos e afazeres. A Banda de Congo se ocupa com os ensaios, manutenção dos instrumentos, preparo da alimentação, questões relacionadas a ritualidade. Nos dois primeiros dias da festa são realizadas apresentações de bandas de fora com estilos musicais de Reggae e Forró pé de Serra.

No terceiro dia acontece a passagem mais esperada do final de semana: o encontro das Bandas de Congo do Espírito Santo. A Banda de Congo São Benedito e a Banda de Congo Mirim são responsáveis em receber e direcionar o cortejo das bandas visitantes. Eles esperam pelos visitantes na praça da vila, onde fazem a primeira recepção e seguem para a igreja e casa do Congo.

\section{Considerações Finais}

Todos os testemunhos trazidos aqui, nesta pesquisa, e tantas outras pessoas que contaram sua história, trazendo suas percepções, ideias, pensamentos e lembranças, embora sejam únicas, particulares, diferentes em tempo e espaços, se encontram na teia maior da construção da memória coletiva da comunidade, evitando talvez o que Peter Burke (2008, p. 88) chamou de "reação a aceleração das mudanças sociais e culturais que ameaçam as identidades, ao separar o que somos daquilo que fomos. "

Observei que as histórias contadas nas entrevistas, significavam as lembranças originadas das experiências de cada uma daquelas pessoas ligado ao contexto de suas vidas, principalmente sobre o rio e o mar e as práticas culturais tradicionais da vila. E ainda, ao contar sua história de vida, esses sujeitos narram a si mesmo, numa relação em que não se separa aquilo que se vive daquilo que se é. Nesse sentido, a construção da memória coletiva é um processo ligado às especificidades que cada sujeito traz de si e do grupo.

Sobre a prática da pescaria, posso dizer que os pescadores possuem uma relação diferenciada com o trabalho. O ritmo desse trabalho é particular e próprio 
ao contexto dos pescadores da vila. O cuidado com o barco, a feitura das redes, as trocas de experiências entre uma conversa e outra, a contação de histórias e a brincadeira com as crianças na beira do rio, tudo isso faz parte da prática da pescaria em Regência Augusta.

Voltemos a história celebrada na Festa do Mastro, ela guarda a trajetória dos escravos que se salvaram de um naufrágio agarrados ao pau de um navio e vem sendo contada e cantada há anos, ou ainda a história do herói Caboclo Bernardo que é símbolo de bravura e orgulho para comunidade. As festas em Regência Augusta celebram a superação, a força de um povo, que muitas vezes é subjugado na história dos livros, mas para a comunidade possui o sentido de resistência e fé. Dona Alda conta a promessa que fez a Santa Catarina em busca de força diante da enfermidade que estava passando. De joelhos ela seguiu a procissão, cantando e rezando, pedindo cura a Santa Catarina, revivendo na festa a coragem dos que se agarraram ao mastro e se salvaram.

No momento da "contação e cantação" das histórias as pessoas revivem as lembranças e as transmitem. Por isso se traz no trabalho a preocupação sobre o hábito de contar histórias. Para que a história continue existindo é preciso que ela seja contada, e que haja ouvintes, e que estes se identifiquem com aquela reminiscência. No momento de rememoração das histórias, os ouvintes que se identificam com as situações descritas sofrem um processo de reconhecimento, de afinidade, tomando para si aquela memória.

Para a Banda de Congo Adulto ter as crianças por perto, no convívio com a prática, é um indício de que as atividades continuarão existindo. Posso dizer que as crianças, para eles, são um motivo para cantar, um motivo para acreditar em dias melhores.

A casa do Congo e a boca da barra são lugares de encontro, onde as histórias são contadas e cantadas. Há na aproximação entre adultos e crianças uma ação pedagógica, momentos atravessados por uma significação própria e reflexiva da comunidade. Se a memória é uma construção coletiva, a memória coletiva é a construção da história do cotidiano dessas pessoas, num movimento de manter os saberes tradicionais acumulados ao longo dos anos, como a Pesca e o Congo, para as próximas gerações. 


\section{Referências}

ATLAS do Folclore Capixaba / Usina de Imagem; Coordenação de Humberto Capai; Fotografias da Usina de Imagem - Espírito Santo, SEBRAE, 2009.

BENJAMIN, Walter. O narrador: considerações sobre a obra de Nikolai Leskov. Magia e técnica, arte e política: ensaios sobre literatura e história da cultura. São Paulo: Brasiliense, 1994, p. 197-221.

BERGAMIM, Evelyn Reis; RABELO, Marcos Prado. AS MEMÓRIAS DE MESTRE TAGIBE ENTRE AS BATIDAS DO CONGO. Revista Espacialidades [online]. 2017, v. 12, n. 2. ISSN 1984-817X.

BURKE, Peter. O que é História Cultural?. 2. ed. Rio de Janeiro: Zahar, 2008.

CANCLINI, Néstor García. As culturas populares no capitalismo. Rio de Janeiro: Brasiliense, 1983.

GEERTZ, Clifford. O saber local: Novos ensaios em antropologia interpretativa. Petrópolis: Vozes, 1997.

HALBWACHS, Maurice. A memória coletiva. 2. ed. São Paulo: Centauro, 2003.

HOUAISS, Antônio. Minidicionário Houaiss da língua portuguesa. 3.ed. Rio de Janeiro: Objetiva, 2008.

LE GOFF, Jaques. História \& Memória. $7^{\text {a }}$ ed. Campinas, SP: Editora da Unicamp, 2013.

LINS, Jacequay. O Congo do Espírito Santo: uma panorâmica musicológica das bandas de Congo. Vitória - ES/2009

MEIHY, José Carlos Sebe Bom; HOLANDA, Fabiola. História Oral: Como Fazer Como Pensar. 2 ed. São Paulo: Contexto, 2015

\section{Histórias Orais}

CARLOS SANGÁLIA. História oral temática. 2018. Entrevista cedida a Patrícia Flávia dos Santos Cau. Regência Augusta/Linhares. 14 de novembro de 2018.

DONA ALDA IVO. História oral temática. 2018. Entrevista cedida a Patrícia Flávia dos Santos Cau. Regência Augusta/Linhares. 06 de janeiro de 2018.

LUCIANA OLIVEIRA. História oral temática. 2018. Entrevista cedida a Patrícia Flávia dos Santos Cau. Regência Augusta/Linhares. 03 de janeiro de 2018.

LEÔNIDAS CARLOS. História oral temática. 2018. Entrevista cedida a Patrícia Flávia dos Santos Cau. Regência Augusta/Linhares. 27 de janeiro de 2018.

MESTRE GUIMALDO (Guimaldo Firmino). História oral temática. 2018. Entrevista cedida a Patrícia Flávia dos Santos Cau. Regência Augusta/Linhares. 03 de junho de 2018. 
ZÉ DE SABINO (Elcio José Souza de Oliveira). História oral temática. 2018. Entrevista cedida a Patrícia Flávia dos Santos Cau. Regência Augusta/Linhares. 10 de fevereiro de 2018.

\section{Sobre a autora}

Patrícia Flávia dos Santos Cau

patriciaflaviacau@gmail.com

Professora de Artes da Rede Estadual de Educação do Estado do Espírito Santo. Atualmente na função de Supervisora Escolar na SRE/Linhares. Mestre em Ensino na Educação Básica pela Universidade Federal do Espírito Santo-UFES. Graduação em Artes Visuais pela Universidade Federal do Espírito Santo-UFES.

\section{Ailton Pereira Morila}

apmorila@gmail.com

Doutor e mestre em educação pela Faculdade de Educação da USP. Bacharel em História pela Faculdade de Filosofia, Letras e Ciências Humanas da USP. Engenheiro Mecânico pela Escola de Engenharia de São Carlos-USP. Professor Associado da Universidade Federal do Espírito Santo. Membro Permanente do Programa de pós-graduação em Ensino na Educação Básica da UFES. 